\title{
THE ROLE OF PARLIAMENT IN GOVERNMENT FORMATION: \\ COMPARATIVE LEGAL ANALYSIS OF UZBEKISTAN AND \\ EUROPEAN STATES
}

\section{Turdiev Khayitjon Usmonkul ugli}

Department Theory of State and Law, Tashkent State University of Law, Tashkent, Uzbekistan.

E-mail: khayitjonturdiyev@gmail.com

\section{ABSTRACT}

This research was carried out on the formation of different types of governments in European countries and analyzed the government formation traditions in parliamentary democracies. The article provides the comparative research in constitutional law. By researching this theme we tended to analyze the possibility of application of European model of government formation to models in Central Asian countries based on the constitutional frameworks and key political, contextual factors that influence the formation of different types of governments. Also these studies provide the processes of government formation in Uzbekistan and the extent to which the government formation processes correspond the European experience. This article attempts to look at the extent to which these models are generally applicable when applied to in our country.

Keywords:

parliamentary democracy, government formation, motion of no confidence, participation of parliament, state governance forms, accountability.

Article Received: 18 October 2020, Revised: 3 November 2020, Accepted: 24 December 2020

\section{Introduction}

The defining feature of parliamentary democracies is the fact that the executive derives its mandate from and is politically responsible to the legislature. This implies that who forms the government is not determined by an election alone, but is the outcome of a bargaining process among the parties represented in the parliament. There are essentially two ways to conceive of parliamentary government: on the one hand as a way to distribute power between the legislative and executive branches of government, and on the other as a way to organize the accountability of the governors to the governed. That parliamentarism is also a form of accountability to the citizens. It may be useful to distinguish further between a minimal and a maximal (or idealtypical) definition of parliamentarism [1]. Minimally, parliamentary government means that the prime minister and his or her cabinet are accountable to the parliamentary majority and can be voted out of office by the latter. More broadly conceived, parliamentarism is a chain of command from voters to individual members of Parliament, from parliamentarians to cabinet members, and from cabinet ministers to civil servants. At each link, a principal (e.g., the parliamentary majority) delegates to an agent (e.g., the prime minister) under a particular set of accountability rules (e.g., the confidence vote procedure. The ideal-typical parliamentary democracy features a single such chain of command in which each principal delegates to a single or multiple noncompeting agents, and where each agent is accountable to one and only one principal. What could be called the unity principle sets parliamentarism apart from other constitutional designs (e.g., United States presidentialism). In reality, of course, the unity principle is nowhere perfectly legislated or observed, even in systems that meet the minimal definition of parliamentary government. Yet, the ideal type and, more generally, the agency framework may be a useful way to understand policymaking in parliamentary system. Parliament plays significant role in government formation. Formation of government in state governance is an important political process in the life of the state and society. Parliamentary participation in the formation of government should be researched 
to improve the mechanism of parliamentary and government relations. Legal scholars have different approaches to the concept of government formation in their research work. In order to conceive the concept of formation a government, it is possible to achieve this first of all by understanding the essence of the definition of "government formation".

According to A.Gogaeva, "formation" in state governance in the narrow sense is the organization of a state body that is not directly elected by the people, and in the broadest sense, it means the formation of a state body by any legal instrument that includes "election", "appointment", "taking office" and "power" [2].

From this point of view, the term "government formation", in our opinion, means holistic formation of the government, and it applies to its personnel in the sense of approval and appointment. After all, members of the government, including the head of the government, assume their office through such processes as approval, sanction and appointment, and a supreme executive body is created. The Law of the Republic of Uzbekistan "On the Cabinet of Ministers of the Republic of Uzbekistan" uses the concept of government formation.

It is well known that the organization and activities of state bodies are classified by various criteria. According to the source of formation, state bodies are divided into primary and secondary state bodies. According to the legal scientist X. Odilkariev, the primary state bodies are the bodies formed by direct elections, the secondary state bodies are the state bodies elected, established or formed by the people [3].

It is obvious, that the government is a secondary state body according to the source of its formation, which is formed by the people's elected parliament and the head of state. For example, the Cabinet of Ministers of the Republic of Uzbekistan and its members are formed by the Oliy Majlis and the President and responsible before them.

M.V.Baglay states that as a rule, the constitution and law regulate in detail the procedure in which the government is formed and its structure. The government plays an important role in developing the main directions of state policy, in determining the means and goals for their implementation. At the same time, the independence of the government from the parliament is reinforcing [4].

B. Alimov notes that "the formation of the government is a complex and responsible process, and how it will be implemented and its results can have a direct impact on the stability of the state mechanism and the effectiveness of state governance. The first and most important step in the constitutional-legal relationship with the formation of the government is the process of approving the head of the government" [5].

K.Jumabaev points out that the legislative branch exercise control over the executive body in various ways. As one of these, parliament participates in the formation of executive bodies and officials[6].

In this regard, we believe that contradictions, balances and cooperation between the head of state and the parliament determines the form of the state governance. The issue of formation of government is determined by the basic law of the state. How this process is implemented depends on the involvement of parliament and the president, through the formation of a supreme executive body so that the highest levels of government officials can exercise their powers. Parliament, through its political forces, represents the interests of the people and it is considered the primary source of the formation of the executive power.

Constitutional models of government formation

2.1. Scientific and legal literatures highlight various models of government formation. The involvement of parliament in this process varies proportionally

V.Chirkin notes that the formation of government is carried out in three ways: nonparliamentary, semi-parliamentary and parliamentary[7]. In this regard, A.Rakhmanov primarily associated formation of the government 
with the constitutional and legal models of the executive branch and divides the government into parliamentary, presidential and mixed types [8]. M.Baglay argues that the emergence of the government is formed in two ways: parliamentary (through the lower house of parliament forces) and by the non-parliamentary (method of presidential republics) [9].

Parliamentary democracy in the parliamentary form of state governance is deeply entrenched and the legislative branch independently forms the executive branch. The participation of the Head of State in this process is symbolic.

Z.Vahidov notes that in parliamentary form of government, a member of the government can usually only be a member of the lower house (UK, Germany, India) [10]. For example, Germany is a parliamentary republic according to the state form.

As stated in the German Constitution, the candidate securing the highest number of votes in Bundestag, for the post of prime minister (federal chancellor) is nominated by the president and elected by parliament [11]. The president only confirms that the chancellor will assume the office.

M.Mirakulov shows that the status of the majority of the presidents of the parliamentary form of government is cercemonial and performs arbitrary and arbitrage-integrative, coordinating functions, and argues the pros and cons, nature of the parliamentary republic, the president's inability to lead the executive branch, and therefore, the president does not have a central role in the form of a parliamentary republic [12].

Thus, the legislative power has the absolute advantage in forming a government in the form of a parliamentary system. However, the head of state is also symbolically participates as a representative elected by the people.

This is the case in many parliamentary monarchy countries. For example, in accordance with the Spanish Constitution, the King will hold consultations with representatives of political parties following the reorganize of members of the
Congress (lower house) and through the chairman of Congress, he proposes a nominee for prime minister to parliament. The candidate must have the absolute majority of confidence votes in parliament [13]. In these countries, parliament has full political power and the government and its members is accountable to the parliament and president.

Formation of government in the form of parliamentary system includes the following general features: First, the government and its leader are nominated by the victorious political forces; secondly, the government should have a parliamentary vote of confidence; third, the government is accountable to parliament, and the government may resign or dissolve parliament through a vote of no confidence; Fourth, the prime minister will have a high position in the system of state authority.

2.2. In the form of presidential rule, parliamentary and governmental relations change essentially and in form. An important aspect of presidential form of government is that the head of state is officially the head of executive power. In this respect, it is fundamentally different from parliamentary and mixed republics. In the form of presidential rule, parliamentary and governmental relations change essentially and in form. An important aspect of presidential form of governance is that the head of state is officially the head of executive power. In this respect, it is fundamentally different from parliamentary and mixed republics.

According to the M.Mirakulov's point of view "in terms of the powers of the President in relation to other branches of government, is the institution executive branch of power [14]". It is known that the presidential republics are divided into states where the prime minister exists and this position is absent. B.Alimov considers that in most of the presidential republics the entire government is formed by the president without the presence of a representative body [15].

This approach implies the participation of parliament in the formation of a government, although some countries have a presidential form 
of governance. The parliament should approve the government and its members. This method of government formation exists in the United States and most Latin American countries.

The United States is a presidential republic. The head of state is the head of the executive branch. The President appoints ministers who are members of the government, with the advice and consent of the Senate. At the same time, the Vice President, who is the postpresident in the US, is the chairman of the Senate. This is because he represents the party that securing the most seats in parliament.

According to the above-mentioned, the issue of forming government in presidential form of governance is as follows. First, the government is formed independently by the president, regardless of the proportion of power in the parliament; second, members with the consent of the head of the government, are appointed by the head of state; third, the government is not accountable to parliament; Fourth, there is no institution of confidence vote or motion of noconfidence; Fifth, the government tender its resignation to the president, not to the newly elected parliament.

2.3. The most important process in the political life of the state is the formation of a mixed government system, balanced between the parliament and the president.

A.Kalinovich believes that the study of the structure of supreme state bodies in modern countries shows that in recent years there are arising many countries with mixed form of government. [16]

L.Simonishvili is an organizational model of state authority, characterized by a synthesis of presidential and parliamentary elements of a mixed form of government [17].

It is worth noting that legal scholars note that a mixed model of state governance for the first time has been formed in France.

In France, the government and prime minister have significant legal status in the system of state authority. Article 20 of the Constitution states: "The government determines the policy of the nation. It has both the administration and the armed forces" [18].

The strengthening or weakening of the government in this country will depend on the political and socio-economic life of the country and on the personal qualities of the president and prime minister.

In the case of France, the presidency is relatively strong within the power branches. The President exercises his powers with the Prime Minister jointly. In addition, the president, elected by the people, ensures concerted functioning and interaction of bodies of state authority.

A.Rahmanov notes that mixed form of governance "is very effective when the president and the government are focused on one political course. In this case, the priority in the executive branch belongs to the president, and the prime minister and the government only implement and introduce the decisions made at the presidential level. However, the issue characterized to the semi-presidential republics is that there is a great deal of possibility of conflict between the president and the prime minister, to determine the government policy" [19].

In summary, the following features of government formation in a mixed form of governance can be highlighted: First, the government is formed by the co-operation and balance between the president and the parliament (often under the priority of parliament); second, members of the government are nominated by the victorious political forces in parliament; thirdly, the executive branch is exercised jointly by the president and the government; fourth, the president is not officially part of the executive branch and ensures concerted functioning and interaction of bodies of state authority; Fifth, the executive is politically accountable to both the parliament and the president.

Government formation in Central and Western Europe

It is well known that the first stage of government formation begins with the determination of the proportion of political forces that won the parliamentary elections. 
T.Mukhtarova notes that the purpose of a political party is to gain power by forming its own government or coalition government which includes its representatives [20]. In foreign countries (Germany, Japan, India), the government is almost in practice formed exclusively as a coalition. In Germany, for example, the government is formed through negotiations based on the results of parliamentary elections. Different political parties or groups won in the elections join together for a particular purpose, usually for a limited time. As political practice show, the most basic types of governments are as follows: single-party majority government (where one party in government controls a parliamentary majority), minimalwinning coalition government (where there is more than one party in government and where the support of each party is needed to maintain a parliamentary majority), surplus coalition government (where there is more than one party in government and where the support of at least one party is not needed to maintain a parliamentary majority), single-party minority government (where there is one party in government, but no parliamentary majority) and coalition minority govern- ment (where there is more than one party in government and where the government does not control a parliamentary majority) [21]. In this list V.V.Sidorov also adds the non-partisan governments in transition period countries or in democracies [22].

It is important to note that in some countries, the composition of the government must be trusted by both chambers of parliament. For example, in accordance with the Article 94 of the Italian Constitution, the government must gain the confidence of both chambers of parliament by voting. Not later than ten days after formation, the Government shall be submitted to the Chambers for gaining trust [23].

In this regard, in the future it is expedient to introduce national legislation the approval of future members of the government by the upper house of parliament. For example, although it is a presidential republic, approval from the Senate requires the appointment of ministers in the United States. Levels of trust in the national government have wide-reaching implications for the vitality of American democracy. [24] In sum trust influences citizens' policy preferences and support for government activities on particular issues [25] their compliance with the law [26], and their assessments of politicians and political institutions.

\section{Models of government formation in Central Asia}

As we have analyzed, the formation of government and the participation of the legislative chamber in it depend on the form of state governance. The issue of classification of the form of state governance in the Commonwealth of Independent States remains controversial among legal scholars.

A.Nechkin believes that Kazakhstan, the Republic of Belarus, Kyrgyzstan and Uzbekistan have the same form of state governance with specific features. [27].

In our opinion, the Russian Federation could also be added to this list. In this country, the president and the parliament do not have absolute authority to form a government. According to the Russian Constitution, the president forms a government. The candidate for the head of the Government must be approved by Parliament. In addition, parliament has the right to vote for a vote of no confidence in the government. Clearly, in most mixed countries (particular CIS countries) except for the French model, the dominance of the head of state in the system of state power develops not by constitutional norms but by the personality traits of the presidents and the national mentality and the process of transition to a democratic state.

\section{Constitutional mechanism of government formation in Uzbekistan}

In the Republic of Uzbekistan in the years of independence through the changes and additions to the Article 98 of the Constitution of Republic of Uzbekistan, first of all legal relations related to the order of the activities of the Cabinet of Ministers, its organization, responsibility, appointment of the Prime Minister and the 
government's interactions with the Parliament and procedure of the presenting the vote of noconfidence were constitutionally-legally regulated [28].

Based on the Constitution, Uzbekistan is a state with a mixed (semi-presidential) form of government. The model of government also has the characteristics of a mixed form of government. In accordance with the Constitution of the Republic of Uzbekistan, the government is formed by the parliament and president of the country on a balance. The Government is accountable to the Oliy Majlis of the Republic of Uzbekistan and the President of the Republic of Uzbekistan in its activities, and the parliament can express a vote of no confidence in the government. At the same time, the head of state elected by the people has the right to dissolve parliament. The basic law of Uzbekistan also states that The President of the Republic of Uzbekistan is the Head of the State and ensures concerted functioning and interaction of bodies of state authority.

It can be concluded that the participation of the President and Parliament in the process of formation of the Cabinet of Ministers in the Republic of Uzbekistan means that the government has directly a political and legal independence in the state power. Parliament's participation in the formation of a government ensures independence of the supreme executive body from the head of state and provides open policy within the framework of the state-wide policy developed by the president.

According to the Constitution of the Republic of Uzbekistan the nominee of a Prime Minister of the Republic of Uzbekistan shall be proposed by political party, securing the highest number of seats in the elections to the Legislative Chamber of the Oliy Majlis of the Republic of Uzbekistar or by several political parties, securing the equa highest number of seats.

For instance, as a result of parliamentary elections in December 2019, the Liberal Democratic Party of Uzbekistan won 53 seats in the Legislative Chamber of the Oliy Majlis, making it the fourth largest parliamentary fraction in the nation's history. This is $35 \%$ of the total number of voters [29]. Thus, the winning party received the right to nominate a prime minister, despite gained a third of the total vote. This rule has its advantages and disadvantages. First, this procedure prevents the second round of elections and gives economic savings and allows voters to choose the right candidate for themselves. Secondly, this system is unique to countries with low-quality and undeveloped political parties that do not represent the interests of most voters. As is obvious, our country is entering a new phase of development. Democratic changes have been made in our society to foster the principles of multi-party politics, political pluralism, openness and transparency"

In developed countries, the government is formed by the majority of the parliament (the party in which the vote is more than half of the total number of deputies, not the party with the highest number of seats).

Therefore, to introduce a rule that a party with a majority $(50 \%+1 \%)$ of the total number of seats in parliament will be empowered to nominate a prime minister will fully represent the interests of voters.

Analyzing about the formation of the Greek government, A. Cherkasov said that the prime minister could be the leader of the party with the absolute majority in parliamentary elections, and if no party has achieved such a result "the President of the Republic will study the possibility of forming a government and grant to the trust of parliament, the leader of the party with the most seats." If this is not possible, "the president will hand over the opportunity to form a government to the leader of the party who secured the second majority of votes in parliament" [30].

Logically, at the same time, a number of political parties may receive equal votes in the elections. Therefore, in order to ensure full participation of political parties in the process of formation of the government and prevent possible political conflicts it is expedient to introduce into the current legislation the legal frameworks of "parliamentary coalition", "coalition agreement 
between parties" and "coalition government". In the literature on coalition theory, government formation is considered as a bargaining game [31] the advantages of a coalition cabinet are two: it widens the legislative support of the government, and it maximizes the commitment of parties to the executive agenda. From the parties' perspectives, the advantage of a coalition cabinet lies in the maximization of their policy influence and of their control of political offices [32].

The Constitution states that the nominee for the post of Prime Minister, upon consideration and approval of his nominee in the Oliy Majlis of the Republic of Uzbekistan, shall present the program of action of the Cabinet of Ministers for a short and long term prospect. In this process, the confidence in the action program of the Head of Government is an important milestone in the future development of the country. According to the experience of foreign countries, it is expedient to introduce into our current legislation the date and the procedure of this action program for discussion in the joint sittings, and the procedure for its approval by voting.

For example, the Constitution of Portugal defines that a government program should be submitted to the Republican Assembly within ten days, its discussion shall not exceed three days, and a majority of the votes of the deputies required to reject the program [33]. It should be noted that in our country, party membership of the head of government is not provided. Sh.Zulfikarov positively estimated the situation and said that "when a political party nominates a prime minister, it is necessary that he propose such a person who deserves the high-office, based on the interests of the state, not his own interests" [34].

The next step in forming the government is to appoint its members. The constitutional law of foreign countries differs the procedure of the formation of government members. In parliamentary republics such as Germany and Bulgaria, parliament only approves the head of government, and ministers are appointed and dismissed by the head of government alone. In some countries, the entire government is elected by parliament. In Switzerland, the government is elected at a joint meeting of both houses of the Federal Assembly [35].

Comparative analysis of Uzbekistan and European states

In constitutional law of foreign countries, different constitutional formulas can be found in the process of forming a government, including the appointment of a head of government. According to A.L.Gogaeva, the formation of government is a complex constitutional process, which usually takes place in two stages: 1) the appointment a head of government; 2) the appointment of government members, ministers [36].

It is well known that the formation of a government begins with the appointment of the prime minister. For example, according to the Portuguese Constitution, "the Prime Minister is appointed by the President after consultations with political parties in the Republican Assembly, taking into account the results of the parliamentary elections" [37]. According to the Romanian Constitution, the President nominates the prime minister after consultations with the absolute majority of party and appoints on the basis of the parliamentary confidence [38]. The Prime Minister of the Republic of Lithuania is appointed by the President through approval by Seim [39]. At the same time, in the constitutions of several countries (Germany, Hungary, Slovenia), "the head of government is elected (approved) by the parliament on the proposal of the president [40].

In the constitutional law of foreign countries, parliament should have a "vote of confidence" in the process of forming a government. Sh.Zulkfikorov believes that in countries where the vote of confidence is expressed to the head of the government, he will be authorized to form and operate his own government, and the government will get "permission" to start his own government [41].

According to the article 98 of the Constitution of the Republic of Uzbekistan The 
nominee of a Prime Minister of the Republic of Uzbekistan shall be proposed by; political party, securing the highest number of seats in the elections to the Legislative Chamber of the Oliy Majlis of the Republic of Uzbekistar or by several political parties, securing the equa highest number of seats. The President of the Republic of Uzbekistan after considering the proposed nominee for the post of Prime Minister, within ten - day term shall propose it for consideration and approval by the chambers of the Oliy Majlis of the Republic of Uzbekistan. A nominee of the Prime Minister shall be deemed as approved, if more than half of the total number of deputies of the Legislative Chamber and members of the Senate of the Oliy Majlis of the Republic of Uzbekistan, respectively, vote for a nominee. In this regard, the confidence of both chambers of the legislative power to the leader of the government determines his position before the president and is supported by the political majority in parliament. B.Alimov believes that it is common practice for a nominee to the head of the government (appointed in some countries) to submit a program of action to the country's representative body (Hungary, France, Greece, Lithuania, Portugal, Finland, Croatia, Slovakia), this is in turn enhances the government's accountability to the parliament and strengthenes the parliamentarism in the state governance. Hearing and discussion of the program of the Prime Minister's candidate in both houses of the parliament reflects its role in the state authority [42].

As R.Khakimov rightly noted, "in the process of the approving the nomination of the Prime minister, Parliament should decide whether to approve it or not according to the analyzing the candidate's plans for future activities, his goals, his vision of the government's action program and, consequently, his activities during his term" [43].

In mixed-government countries, apart from the prime minister, members of the government are formed independently by the head of state, assuming the partial involvement of parliament. When forming the government, the ratio of parties in parliament is taken into account In France, members of the government are appointed by the president on the proposal of the Prime Minister.

At the same time, parliament's participation in government formation is based on world experience and determined in some countries (Hungary, Bulgaria, Greece, Lithuania, Turkey, Croatia, Estonia) where members of the government take an oath before parliament, in some countries (UK, India, Albania, Greece, Australia) that a government member should be a member of parliament. [44].

Amendments and additions have been made to the Constitution and other legislative acts of the Republic of Uzbekistan in connection with democratization of the order formation of the government and strengthening of its responsibility. The practice of approval and dismissal of the members of the Cabinet of Ministers following the approval of the Legislative Chamber on the proposal of the Prime Minister and sanction by the President was introduced. [45].When considering and approving his candidacy in the Legislative Chamber, a candidate for the position of a member of the Cabinet of Ministers of the Republic of Uzbekistan presents an action plan that provides for legal, economic, social, organizational and technical measures to achieve long-term targets and interrelated with the program of actions of the Cabinet of Ministers of the Republic of Uzbekistan. After that, a certain conclusion is reached. France and Italy are among the countries that have introduced a procedure for consideration and approval by members of the lower house of parliament.

\section{Conclusions}

In conclusion, the concept of "government formation" is used to establish a collegial government body, which is formed through the approval, appointment, and sanction of government members made up of collegiate officials. The process of forming a government usually involves the following three stages: the nomination of the head of government and the confidence in parliament and the government program, as well as the formation of other 
members of the government. This process is divided into non-parliamentary, parliamentary and semi-parliamentary (mixed) methods in the form of public administration.

In our country, the government is formed through joint participation of the head of state and the parliament. Participation of the Oliy Majlis in the formation of the Cabinet of Ministers in the Republic of Uzbekistan fully reflects the constitutional principle of influence on the composition of the government and the responsibility of the government before the parliament. This in turn, reflects that the Cabinet of Ministers is constitutional-legal independent branch of the state power from the head of the state. At the same time, it's the constitutional right of the President taking into account the national interests to represent for consideration and approval by the chambers of the Oliy Majlis of the Republic of Uzbekistan a nominee of the Prime Minister of the Republic of Uzbekistan. Parliament's participation in the formation of the Cabinet of Ministers - the collegial body of the executive body is a form of preliminary control of members of the government.

The full realization of the principle "The state shall express the will of the people and serve their interests" can be achieved by further democratization of the formation of the executive branch. At the same time, in order to fully participation of parliamentary chambers and represent and harmonize the interests of citizens it is necessary to increase the role of political parties in forming the government.

\section{References}

[1] Institutions and Strategy in Parliamentary Democracy: Rationalizing Parliament: Legislative Institutions and Party Politics in France by John D. Huber; Making and Breaking Governments: Cabinets and Legislatures in Parliamentary Democracies by Michael Laver and Kenneth A. Shepsle Review by: Kaare Strøm. Source: Legislative Studies Quarterly, Vol. 23, No. 1 (Feb., 1998), pp. 127-143 Published by:
Washington

University. https://www.jstor.org/stable/440218

[2] A.Gogaeva Formation of the government of the Russian Federation - Author. Diss. cand. legal sciences. - Moscow, 2004.- P. 10.

[3] Theory of state and law / Odilkariev H.T, Tulteev I.T. and et al; Edited by prof. Odilkariev H.T. - Tashkent: Academy of the Ministry of Internal Affairs of the Republic of Uzbekistan, 2009. - P. 149.

[4] Constitutional law of foreign countries / Edited Corr. RAN, prof. M.V. Baglaya, doctor of legal science, prof. Y.I. Leibo and doctor of legal science, prof. L.M.Entina. M .: Norma, 2004 .- P.-278.

[5] B.Alimov Relationship between the President and the Cabinet of Ministers in the system of state authority of the Republic of Uzbekistan: Philosophy in Law. (PhD) diss ... - Tashkent: TSUL, 2017. -P. 56.

[6] K.Jumabaev Legislative and executive authorities: interconnection and interaction: diss. for the degree of cand.of legal science.. - Tashkent: TSIL, 1993. - P. 5253.

[7] V.Chirkin Constitutional law of foreign countries. - M .: Norma Infra-M, 2010 .- P 608.// B.Alimov Relationship between the President and the Cabinet of Ministers in the system of state authority of the Republic of Uzbekistan: Philosophy in Law. (PhD) diss ... - Tashkent: TSUL, 2017. - P. 56.

[8] Rakhmanov A. The constitutional-legal status of the Cabinet Ministers of Republic of Uzbekistan: diss. for the degree of candidate of legal sciences.. - Tashkent: TSUL, 2008. - P. 30-31.

[9] Constitutional law of foreign countries / Edited Corr. RAN, prof. M.V. Baglaya, doctor of legal science, prof. Y.I. Leibo and doctor of legal science, prof. L.M.Entina. M: Norma, 2004 .- P.-283. 
[10] Vohidov Z. Practical expression of the principle of separation of powers in the Republic of Uzbekistan: diss. for the degree of candidate of legal. science. - Tashkent: The Academy of Public Administration under the President of the Republic of Uzbekistan (APA), 2000. - P. 109.

[11] https://legalns.com/download/books/cons/g ermany.pdf

[12] M.Mirakulov Constitutional-legal status of the President of the Republic of Uzbekistan (comparative-legal analysis) Doctor of legal sciences diss.autoref ... - Tashkent: APA, 2016. - P. 18.

[13] https://legalns.com/download/books/cons/s pain.pdf

[14] M.Mirakulov Constitutional-legal status of the President of the Republic of Uzbekistan (comparative-legal analysis) Doctor of legal sciences diss.autoreferat ... - Tashkent: APA, 2016. - P. 16.

[15] B.Alimov Relationship between the President and the Cabinet of Ministers in the system of state authority of the Republic of Uzbekistan: Philosophy in Law. (PhD) diss ... - Tashkent: TSUL, 2017. -P. 57.

[16] A.Kalinovich Forms of government in legal state (theoretical and legal aspect) Autoreferat. ... cand. legal sciences. - St. Petersburg, 2008 .- p. 3.

[17] L.Simonashvili State-legal model of the Republic with a mixed form of governance (theoretical analysis) - Autoreferat of cand. legal sciences. - Moscow, 2005 .- P. 7.

[18] Constitution of the French Republic [Text] translator X.Fayziev. - Bukhara Publishing House, 2018. - P. 9.

[19] Rakhmanov A. The constitutional-legal status of the Cabinet Ministers of Republic of Uzbekistan: diss. for the degree of candidate of legal sciences.. - Tashkent: TSUL, 2008. - P. 35.

[20] T.S. Mukhtarova The role of political parties in the development of civil society in Uzbekistan // Philosophical sciences, European science №2 (44) 2019. - P. 33.

[21] Malkhaz Nakashidze. Government formation and cabinet types in new democracies: Armenia andGeorgia in comparative European perspective International Comparative Jurisprudence 2(2016)25-35. Journal homepage: www.elsevier.com/locate/icj.

[22] V.Sidorov Dynamics of coalition governments in parliamentary democracies. Scientific notes of Kazan University, Humanitarian science. 153, 2011, - P. 191192.

[23] https://legalns.com/download/books/cons/it aly.pdf

[24] Joseph Gershtenson, Jeffrey Ladewig and Dennis L. Plane Parties, Institutional Control, and Trust in Government Social Science Quarterly, Vol. 87, No. 4 (december 2006), pp. 882-902 Published by: Wiley Stable URL: https://www.jstor.org/stable/42956164 Accessed: 07-02-2020 06:06 UTC

[25] Hetherington, Marc J., and Suzanne Globetti. 2002 "Political Trust and Racial Policy Preferences. "American Journal of Political science". - P.

[26] Scholz, John T., and Mark Lubell. 1998. "Trust and Taxpaying: Testing the Heuristic Approach to Collective Action." American Journal of Political Science. - P. 417.

[27] Constitutional law of foreign countries /A.V.Nechkin. - M.: Yurayt Publishing $\begin{array}{llll}\text { House, } & 2019 . & -P . & 143 . / /\end{array}$ https://books.google.co.uz/books.

[28] Commentary to the Constitution of the Republic of Uzbekistan. Authors' team. Second edited and Completed. Tashkent: Uzbekistan, 2013., P. - 415. 2013., P. 415.

[29] UzLiDeP decided to nominate A. Aripov for the post of Prime Minister// https://www.uzlidep.uz/positionparty/302

[30] Cherkasov A.I. The Institute of Government in Foreign Countries: the 
Formation Procedure and Responsibility / State and Law, 2013, No. 1. - P. 75. // Tulteev I.T, Zulfiqorov S. Development of interaction between the branches of government in the Republic of Uzbekistan (on the example of parliament and government). Information and analytical material. - T .: TSUL, 2016 .P. 18.

[31] Lupia,

A.,

$\&$ Strom,K.

(2010).Bargaining,transaction costs, and coalition governance.InK.Strom(Ed.),

Cabinets and Coalition Bargaining, The Democractic Life Cyclein Western Europe (pp. 51-85). Oxford: Oxford University Press.

[32] Cabinet Formation in Presidential Regimes: An Analysis of 10 Latin American Countries by Octavio Amorim neto Instituto Universitário de Pesquisas do Rio de Janeiro (IUPERJ). Prepared at the 1998 meeting of the Latin American Studies Association, The Palmer House Hilton Hotel, Illinois, September 24-26, 1998.

[33] https://legalns.com/download/books/cons/p ortugal.pdf

[34] Sh.Zulfikarov. Interaction of Parliament and Government: A Comparative-Legal Analysis. Monograph. // - Tashkent: TSUL Publishing House, 2015. - P. 106.

[35] Constitutional law of foreign states/ responsible editor: prof. AA Azizkhojaev: T.: TSUL, 2010. - P. 480.

[36] A.Gogaeva Formation of the government of the Russian Federation - Author. Diss. . cand. legal sciences. - Moscow, 2004 .- P. 10.

[37] https://legalns.com/download/books/cons/p ortugal.pdf

[38] https://legalns.com/download/books/cons/r omania.pdf
[39] https://legalns.com/download/books/cons/li thuania.pdf

[40] Sh.Zulfikarov. Interaction of Parliament and Government: A Comparative-Legal Analysis. Monograph. // - Tashkent: TSUL Publishing House, 2015. - P. 100.

[41] Sh.Zulfikarov. Interaction of Parliament and Government: A Comparative-Legal Analysis. Monograph. // - Tashkent: TSUL Publishing House, 2015. - P. 100.

[42] B.Alimov Relationship between the President and the Cabinet of Ministers in the system of state authority of the Republic of Uzbekistan: Philosophy in Law. (PhD) diss ... - Tashkent: TSUL, 2017. -P. 56.

[43] R.R.Khakimov Parliament in the system of state power: Problems of theory and practice: Monograph. - Responsible editor: candidate of legal science F.E.Mukhamedov. - Printing office of the Institute for Monitoring of Current Legislation under the President of the Republic of Uzbekistan - Tashkent: 2012. p. 78.

[44] B.Alimov Relationship between the President and the Cabinet of Ministers in the system of state authority of the Republic of Uzbekistan: Philosophy in Law. (PhD) diss ... - Tashkent: TSUL, 2017. -P. 72.

[45] Law on introducing amendments and additions to some legislative acts of the Republic of Uzbekistan in connection with democratization of the order formation of the government and strengthening of its responsibility // National Legislation Database, 03/06/2019, No. 03/19/527/2706. 